\section{Need of Alertness on Porcine Circovirus 2 in North East India}

\section{Rajesh JB ${ }^{1 *}$, Rajkhowa $\mathrm{S}^{2}$, Dimri U ${ }^{3}$, Prasad H', Sarma K' and Behera SK ${ }^{1}$}

'Department of Veterinary Medicine, College of Veterinary Sciences and Animal Husbandry, Central Agricultural University, Selesih PO, Aizawl, Mizoram 796015, India

${ }^{2}$ Indian Council for Agricultural Research-National Research Centre on Pigs, Rani, Guwahati, Assam, 781131, India

${ }^{3}$ Indian Council for Agricultural Research-Indian Veterinary Research Institute, Izatnagar, Bareilly, Uttar Pradesh, 243122, India
Received: 11 April, 2020

Accepted: 15 May, 2020

Published: 16 May, 2020

*Corresponding author: Rajesh JB, Department of Veterinary Medicine, College of Veterinary Sciences and Animal Husbandry, Central Agricultural University, Selesih PO, Aizawl, Mizoram 796015, India,

E-mail:Rajesh leovet@gmail.com

https://www.peertechz.com

Check for updates

\section{Introduction}

The domestic pig originated from the Eurasian wild boar (Sus scrofa) and its domestication started approximately 9,000 years ago [1]. Asian pig domestication appeared to have occurred mainly in North-eastern India, the Mekong region, and the middle and downstream regions of the Yangtze River [2]. The pig population in India is 8.8 million, which is $1.09 \%$ of the world's pig population of 967.38 million [3]. India shares only $5.23 \%$ of total pork meat production in the world. North Eastern (NE) region of India contributes $28 \%$ of India's total pig population. Among the total pork production in the country, $50 \%$ is used in the NE region that includes own production and imported pigs [4]. Pig population contributed by the North Eastern Indian states are Assam (15.89\%), Manipur (2.69\%), Mizoram (2.38\%), Meghalaya (5.27\%), Nagaland (4.89\%), Tripura (3.52\%) and Sikkim (0.29\%) [5]. The system of pig production in NE Region of India is unique and traditional where rearing pigs and eating pork are part of their culture. Backyard system of pig rearing is seen here as pigs are highly prolific, fast growing with proven demand and available ready market, resulting in quick generation of income.

\section{Porcine circovirus 2 infection in pigs}

Pigs are susceptible to many viral infections which lead to huge morbidity and mortality resulting in considerable economic losses to pig rearers. The important viral diseases among pigs in India are Classical Swine Fever, Rotavirus infection, Foot and Mouth Disease and Porcine Reproductive and Respiratory syndrome. Along with these established maladies, other emerging diseases pose threat to economic pig farming. One such emerging disease is Porcine Circovirus 2 (PCV2) infection which was reported for the first time from Canada in 1991 [6]. There are four types of porcine circovirus, namely PCV1, PCV2, PCV3 and PCV4 of which PCV2, PCV3 [7] and PCV4 [8], are considered to be pathogenic. PCV2 sub-clinical infection is the most common form of PCV2 [8]. Postweaning Multisystemic Wasting Syndrome (PMWS) is a form of PCV2 infection that can increase mortality as well as reduction in the daily weight gain in weaner pigs [9]. PMWS can be transmitted by pig-to-pig direct contact whereas some studies point towards the possible role of airborne transmission. Porcine circovirus 2 (PCV2) causes different forms of disease viz. Porcine Respiratory Disease Complex (PRDC), enteritis, Proliferative and Necrotizing Pneumonia (PNP) and Porcine Dermatitis and Nephropathy Syndrome (PDNS) [10]. The main symptoms are emaciation, icterus, dyspnoea and pallor in pigs of weaning and post-weaning age groups. Lymphadenomegaly is reported in PCV2 infection [11].

Wasting, unthriftiness, skin paleness, jaundice, enlarged lymph nodes and diarrhea are the important clinicopathological manifestations of PCV2 infection. The predilection site for PCV2 is the immune system where it preferentially targets lymphoid tissue depletion and histiocytic replacement, leading to observable typical histological lesions. The macroscopic findings in necropsy are wasting, non-collapsed lungs, pulmonary consolidation and enlargement of lymph nodes. Lymphoid depletion, syncytia formation (giant cells), histiocytes infiltration and histiocytic cells show botryoid inclusions [12]. 
Several studies have reported reproductive problems associated with PCV infection [13]. Reproductive failures associated with PCV2 have been reported in Canada, Italy, Germany [14] and India [15]. In an investigation to ascertain reproductive failures and neonatal mortality caused by PCV2 by detecting viral antigen and nucleic acids in tissues of stillborn and dead neonatal pigs in Tamil Nadu Kumar, et al [16], confirmed the presence of porcine circovirus 2 in pooled organ samples. Virus isolation together with PCR assay helped to establish the PCV2 etiology in pneumonia and wasting of pigs encountered in their study.

\section{Consequences of PCV2 infection}

Heavy economic loss in affected herds was reported due to significant increase in post-weaning mortality [17]. PCV2 infection is reported to be present in every major swineproducing country in the world and the number of cases of Porcine circovirus associated disease (PCVAD) is rapidly increasing. It is considered as the most devastating disease in Korean livestock history, since its first outbreak in 1999 [18] An estimate in United States shows that PCV2 infection leads to an average loss of 3-4 dollars per pig to 20 dollars per pig in severe outbreak [19]. Grau-Roma, et al. [20], proposed that the diagnosis should be based on a significant increase in postweaning mortality and 'wasting', and positive findings in at least $1 / 5$ pigs post mortem.

\section{Porcine Circovirus 2 infection in north east india}

Bhattacharjee, et al. [21], reported the complete genome sequence of PCV2a and PCV2b from NE states of India. A prevalence rate of $11.56 \%$ for PCV2 was reported by Pegu, et al. [22], in 1064 serum samples of pigs collected from North Eastern states of India. In a similar study by Mukherjee, et al. [23], in Meghalaya a mean positivity of $18.94 \%$ was reported for PCV2. In another study, Mukherjee, et al, [24] reported highest antibody prevalence of PCV2 as $80.8 \%$ in $2014,79.1 \%$ in 2015 and $96.2 \%$ in 2016 in Meghalaya. A comprehensive study of PCV2 and its incidences in the North East India from 2011 to 2017 indicated $31.27 \%$ mean positivity of PCV2 antibodies in the area [25]. In a comprehensive prevalence study, Rajesh, et al. [26,27], reported $49.35 \%$ prevalence of PCV2 in samples collected from all the NEH states.

In India, only scanty studies are being conducted to track the epidemiological pattern of PCV2. In comparison with other diagnostic assays, LAMP is less time consuming with ease of performance and high specificity to detect specific nucleic acid sequence in clinical samples as well as can be performed in field level with minimum requirements. It is to mention that every study conducted about PCV2 in NEH region give the alarming situation about the PCV2 prevalence among pigs. It is high time to think about the preventive measures and control measures so that the disease prevalence can be curtailed.

\section{Acknowledgements}

Prevalence of PCV2 in NE region was a part of PhD work of first author. The authors are thankful to the Director, ICAR-IVRI and Vice Chancellor, CAU, Imphal for the provisions given for conducting the study.

\section{References}

1. Giuffra E, Kijas JMH, Amarger V, Carlborg O, Jeon JT, et al. (2000) The Origin of the Domestic Pig: Independent Domestication and Subsequent Introgression. Genetics 154: 1785-179. Link: https://bit.ly/3bAXER8

2. Yang S, Zhang H, Mao H, Yan D, Lu S, et al. (2011) The Local Origin of the Tibetan Pig and Additional Insights into the Origin of Asian Pigs. PloS One 6: e28215. Link: https://bit.ly/2WU1oHO

3. FAOSTAT (2017) http://www.fao.org/faostat/en/\#data/QA/visualize. A85.

4. Haldar A, Das D. Saha B, Pal P, Das S, et al. (2017) Smallholder Pig Farming for Rural Livelihoods and Food Security in North East. Indian Journal of Animal Research 3: 471-481. Link: https://bit.ly/3bGIScp

5. 19th Livestock Census (2012) All India Report, Ministry Of Agriculture Department of Animal Husbandry, Dairying and Fisheries, Krishi Bhawan, New Delhi 75- 80

6. Gillespie J, Opriessnig T, Meng XJ, Pelzer K, Maxwell VB (2009) Porcine Circovirus Type 2 and Porcine Circovirus-Associated Disease. J Vet Intern Med 23: 1151-1163. Link: https://bit.ly/362itn8

7. Stadejek T, Woźniak A, Miłek D, Biernacka K (2017) First detection of porcine circovirus type 3 (PCV3) on commercial pig farms in Poland. Transbound Emerg Dis 64: 1350-1353. Link: https://bit.ly/3cBTmKD

8. Zhang H, Hu W, Li T, Liu T, Zhou J, et al. (2019). Novel circovirus species identified in farmed pigs designated as Porcine circovirus 4, Hunan province, China. Transbound Emerg Dis. Link: https://bit.ly/2X3yc14

9. Meng XJ (2012) Spread like a wildfire-the omnipresence of porcine circovirus type 2 (PCV2) and its ever-expanding association with diseases in pigs. Virus Res164: 1-3. Link: https://bit.ly/2zFoVEA

10. Segales J (2012) Porcine circovirus type 2 (PCV2) infections: clinical signs, pathology and laboratory diagnosis. Virus Res 164: 10-19. Link: https://bit.ly/3dSK8cO

11. Afolabi KO, Iweriebo, BC, Okoh Al, Obi LC (2017) Global Status of Porcine circovirus Type 2 and its Associated Diseases in Sub-Saharan Africa. Adv Virol 1-16. Link: https://bit.ly/3fTOVyh

12. Dea M (2010) Porcine circovirus infection. Australia \& New Zealand Standard Diagnostic Procedure. Animal Health Laboratories Department of Agriculture and Food WA 3 Baron-Hay Court, South Perth WA 6151. 1-20. Link: https://bit.ly/2Ta2xdc

13. Madson DM, Opriessnig T (2011) Effect of porcine circovirus type 2 (PCV2) infections on reproduction: disease, vertical transmission, diagnostics and vaccination. Anim Health Res Rev 12: 47-65. Link: https://bit.ly/3dWgjsd

14. O'Connor B, Grauvreau H, West K, Bogdan J, Ayroud M, et al. (2001) Multiple PCV2-associated abortions and reproductive failure in a multisite swine production unit. Can Vet J 42: 551-553. Link: https://bit.ly/2z1CZIA

15. Sharma R, Saikumar G. (2010). Porcine parvovirus- and porcine circovirus 2 associated reproductive failure and neonatal mortality in crossbred Indian pigs. Trop Anim Health Prod 2: 515-522. Link: https://bit.ly/2LDK58F

16. Kumar SK, Selvaraj R, Hariharan T, Chanrahassan C, Reddy YKM (2014) Porcine Circovirus - 2 An Emerging Disease of Crossbred Pigs in Tamil Nadu, India. Int J Environ Sci Technol (Tehran) 3: 1268-1272. Link: https://bit.ly/2WCwQve

17. Baekbo P, Kristensen CS, Larsen LE (2012) Porcine Circovirus Diseases: A review of PMWS. Blackwell Verlag GmbH. Transbound Emerg Dis 59: 6067. Link: https://bit.ly/361MaVB

18. Chae $C$ (2012) Porcine circovirus type 2 and its associated diseases in Korea Virus Res 164: 107-113. Link: https://bit.ly/2Z8ihBy 
19. EllisJ,HassardL,ClarkE,Harding J,AllanG,etal.(1998)Isolation ofCircovirusfrom lesions of pigs with post weaning multisystemic wasting syndrome. Can Vet $J$ 39: 44-51. Link: https://bit.ly/2Lutqoh

20. Grau-Roma L, Fraile L, Segalés J (2011) Recent advances in the epidemiology, diagnosis and control of diseases caused by porcine circovirus type. Vet $J$ 187: 23-32. Link: https://bit.ly/3bAViBM

21. Bhattacharjee U, Ahuja A, Sharma I, Karam A, Chakraborty AK, et al. (2015) Complete genome sequence of emerging porcine circovirus types $2 a$ and $2 b$ from India. Genome Announc 3: e00087-15. Link: https://bit.ly/2T7P85K

22. Pegu SR, Sarma DK, Rajkhowa S, Choudhary M (2017) Seroprevalence and Pathology of important viral pathogens causing reproductive problems in domestic pigs of NE India. Journal of Entomology and Zoological Studies 5 1816-1818. Link: https://bit.ly/2WZXLjQ

23. Mukherjee P, Karam A, Barkalita L, Borah P, Chakraborty AK, et al. (2018) Porcine circovirus 2 in the North Eastern region of India: Disease prevalence and genetic variation among the isolates from areas of intensive pig rearing. Acta Trop 182: 166-172. Link: https://bit.ly/3bDKF10

24. Mukherjee $P$, Karam $K$, Singh $U$, Chakraborty, AK, Huidrom $S$, et al (2018) Seroprevalence of selected viral pathogens in pigs reared in organized farms of Meghalaya from 2014 to 16. Vet World 11: 42-47. Link: https://bit.ly/3dUyKNT

25. Barman NN, Nath B, Kumar V, Sen A, Dutta TK, et al. (2018) The emergence of porcine circovirus 2 infections in the Northeastern part of India: A retrospective study from 2011 to 2017. Transbound Emerg Dis 65: 19591967. Link: https://bit.ly/36aHpZN

26. Rajesh JB, Rajkhowa S, Dimri U, Prasad H, Pegu SR, et al. (2019) Seroprevalence of PCV2 in north eastern hill states of India. Indian Journal of Animal Sciences 89: 119-122. Link: https://bit.ly/2Tbvci9

27. Ellis J (2014) Porcine circovirus: a historical perspective. Vet Pathol 51: 315 327. Link: https://bit.ly/2Zak2hw
Discover a bigger Impact and Visibility of your article publication with

\section{Peertechz Publications}

\section{Highlights}

* Signatory publisher of ORCID

* Signatory Publisher of DORA (San Francisco Declaration on Research Assessment)

* Articles archived in worlds' renowned service providers such as Portico, CNKI, AGRIS, TDNet, Base (Bielefeld University Library), CrossRef, Scilit, J-Gate etc.

* Journals indexed in ICMJE, SHERPA/ROMEO, Google Scholar etc.

- OAI-PMH (Open Archives Initiative Protocol for Metadata Harvesting)

* Dedicated Editorial Board for every journal

* Accurate and rapid peer-review process

* Increased citations of published articles through promotions

* Reduced timeline for article publication

Submit your articles and experience a new surge in publication services

(https://www.peertechz.com/submission).

Peertechz journals wishes everlasting success in your every endeavours.

Copyright: @ 2020 Rajesh JB, et al. This is an open-access article distributed under the terms of the Creative Commons Attribution License, which permits unrestricted use, distribution, and reproduction in any medium, provided the original author and source are credited. 